Burger, F. C. (1990): Provenance, family and individual plus tree selection in an 11 year old $E$. fastigata progeny/provenance trial. Eucalypt breeding cooperative report, Rotorua, New Zealand.

Cannon, P. G. and C. J. A. Shelbourne (1993): Forward selection plots in breeding programmes with insectpollinated tree species. New Zealand Journal of Forest Science 23(1): 3-9.

El-Kassaby, Y. A., T. FundA and B. S. K. LAI (2010): Female reproductive success variation in a pseudotsuga menziesii seed orchard as revealed by pedigree reconstruction from a bulk seed collection. Journal of Heredity 101(2): 164-168.

EldRIDGe, K., J. Davidson, C. Harwood and G. V. WYK (1993): Eucalypt domestication and breeding. Clarendon Press, Oxford.

Griffin, A. R. and P. P. CotTerill (1988): Genetic variation in growth of outcrossed, selfed and open-pollinated progenies of Eucalyptus regnans and some implications for breeding strategy. Silvae Genetica 37: 124-131.

Jones, T. G., R. M. MCConnochie, C. J. A. Shelbourne and C. B. Low (2010): Sawing and grade recovery of 25-yearold Eucalyptus fastigata, E. globoidea, E. muelleriana and E. pilularis. New Zealand Journal of Forest Science 40: $19-31$.

GEA, L. D., R. M. MCConNochie and S. Wynyard (2007): Parental reconstruction for breeding, deployment, and seed-orchard management of Eucalyptus nitens. New Zealand Journal of Forest Science 37(1): 23-36.
Gilmour, A. R., B. J. Gogel, B. R. Cullis and R. Thompson (2009): ASReml User Guide Release 3.0 VSN International Ltd, Hemel Hempstead, HP1 1ES, UK. www.vsni.co.uk.

Kirst, M., C. M. Cordeiro, G. D. S. P. Rezende and D. Grattapaglia (2005): Power of microsatellite markers for fingerprinting and parentage analysis in Eucalyptus grandis breeding populations. Journal of Heredity 96(2): 161-166.

Lambeth, C., B. C. Lee, D. O'Malley and N. Wheeler (2001): Polymix breeding with parental analysis of progeny: An alternative to full-sib breeding and testing. Theoretical and Applied Genetics 103(6-7): 930-943.

Low, C., H. Dungey, T. Stovold and I. Nicholas (2009): A breeding plan for New Zealand Eucalyptus fastigata. FFR Internal Report, SCION, New Zealand.

Nesbitt, K. A., B. M. Potts, R. E. Vaillancourt and J. B. REID (1997): Fingerprinting and pedigree analysis in Eucalyptus globulus using RAPDs. Silvae Genetica 46(1): 6-11.

WILCOX, M. D. (1980): Genetic improvement of eucalypts in New Zealand. New Zealand Journal of Forest Science 10(2): 343-359.

WILCOX, M. D. (1982): Genetic variation in frost tolerance, early height growth, and incidence of forking among and within provenances of Eucalyptus fastigata. New Zealand Journal of Forest Science 12(3): 510-524.

\title{
Threshold selection for rust resistance in hybrid poplar: Population response to mass selection
}

\author{
By B. J. StANTON*)
}

(Received $1^{\text {st }}$ February 2011)

\begin{abstract}
Eleven Populus $\times$ generosa populations were developed in the Pacific Northwest by annual controlled hybridization of P.deltoides and P.trichocarpa between 1991 and 2001. Mass selection for Melampsora leaf rust resistance was observed in the field as a threshold character in identifying seedling phenotypes for clonally replicated evaluation. The effectiveness of the approach was assessed for each annual population by comparing the distribution of phenotypes in unselected seedling populations with the distribution of selected genotypes in the clonal field tests established in successive years and evaluated at the approximate same level of disease severity using two selection thresholds corresponding to chlorotic and healthy tissue. Bi-directional selection was used as an initial check on the efficacy of the procedure

\footnotetext{
*) Corresponding author: BRIAN J. StANTON. Chief Science Officer, GreenWood Resources, 1500 SW First Avenue, Portland, Oregon, U. S. A. 97201. Tel: 971-533-7052, Fax: 503-478-0751. EMail: brian.stanton@gwrglobal.com
}

and resulted in a wide separation in liability between the positive (0.06 threshold units (T.U.)) and negative (-2.45 T. U.) selection groups when tested as clones. The other 10 seedling populations that were subjected solely to directional selection exhibited a mean increase in incidence above the first selection threshold at the clonal stage (47 versus $81 \%$ ) that was accompanied by an improvement in population liability $(-0.06$ versus 0.50 T. U.) and a reduction in population standard deviation ( 0.83 versus 0.54 T.U.). The change in liability was strongly related by polynomial regression to selection intensity and a grouping of populations based on infection-season precipitation $\left(r^{2}=0.98\right)$. The mean liability of four of the 10 seedling populations observed during years of high infection-season rainfall was six-fold lower than the mean liability of those populations observed during the other six years of lower infection-season rainfall (-0.12 T. U. versus -0.02 T. U., respectively), indicating that populations undergoing evaluation during years of heavy precipitation experienced more intense rust exposure. Moreover, quadratic functions showed that 
populations undergoing rust evaluation during years of high rainfall were more responsive to increases in selection intensity above the vertex of the function (i.e. 13.20 versus 3.43 T.U.). Realized heritability averaged 0.63 for all ten populations subjected solely to directional selection.

Key words: Populus, genetic improvement, tree breeding, Melampsora infection, leaf rust.

\section{Introduction}

Populus $\times$ generosa Henry $($ P. deltoides $\times$ P.trichocarpa and reciprocal) is the principal inter-specific hybrid taxon of poplar cultivation in the Pacific Northwest's lower Columbia River Valley of Oregon and Washington, U. S. A. The first commercial varieties were bred from black cottonwood (P. trichocarpa Torr. \& Gray) from the Pacific Northwest and eastern cottonwood (P. deltoides Bartr. ex Marsh.) from the mid and lower Mississippi River Valley during the early 1980s (STETTLER et al., 1988). From the outset of plantation development in 1983, the taxon showed extremely high levels of resistance to the native rust pathogen, Melampsora occidentalis H. Jacks. But in 1991, two pathogens, M. medusae Thuem. from eastern North America and M. larici-populina Kleb. from Eurasia, simultaneously became established in the region with a concomitant change in host resistance and the loss of several commercial varieties (NewCombe and Chastagner, 1993a; NewCombe and Chastagner, 1993b; NewCOMBe et al., 1994). Industrial $P$. $\times$ generosa hybridization programs responded by emphasizing mass selection for rust resistance as the sole criterion used to truncate inter-specific seedling populations for clonally replicated field trials. This tactic was based on reports of reasonably good correlations between one-year-old nursery rust ratings and those observed in rotation-age clonal field trials (CHIBA and NAGATA, 1972; Theilges et al., 1989; Newcombe et al. 1994). Shortly thereafter, in $1995 \mathrm{M} . \times$ columbiana G. Newc., the inter-specific hybrid of $M$. occidentalis and $M$. medusae, appeared and again the distribution of poplar resistance was altered (NEWCOMBE et al., 2000). By 1997, $M$. $\times$ columbiana was the only taxon found in a survey of the leaf rust population of the lower Columbia River Valley.

Melampsora species are obligate biotrophic parasites that cycle annually between their coniferous, aecial hosts and their poplar, telial hosts. Aeciospores disseminated from conifer hosts in the spring germinate on poplar leaves followed by infection. The resulting uredinia on poplar leaves produce urediniospores that germinate and generate infection, leading to multiple cycles of disease during the summer. Severe disease results in premature defoliation. The pathology literature describes two Populus reactions to Melampsora: (1) an incompatible type involving hypersensitive necrosis to contain the initial infection with no observable uredinial-stage symptoms, and (2) a compatible type in which the metrics of the uredinial stage - interval between infection and appearance of uredinia (i.e. the latent period), the size and density of uredinia on leaf surfaces, and the rate of uredinia sporulation - are clearly discernible (HuBBES, 1979). While both reaction types describe separate parts of the infection process, the expression of their symptoms may not be controlled by wholly different host genetic systems (LEFEVRE et al., 1994); HEATHER and CHANDRASHEKAR (1982) observed the hypersensitive response to be associated with minute uredinia, as did NEWCOMBE et al. (2001) who recognized a size and distribution continuum of Melampsora uredinia spanning incompatible and compatible reaction classes. More recently, DowkIW and BASTIEN (2007) showed that incompatible and compatible reactions are correlated in the first $P . \times$ generosa generation, though this association went unobserved in a similar study of the second generation (WoO and NEWCOMBE, 2003).

The hybridization program that developed in response to the 1991 change in pathogen species was designed as a non-recurrent, short-term improvement approach. With it the first $P . \times$ generosa generation was annually recreated over an 11-year period (1991-2001) and screened in one-year-old nurseries to identify putatively resistant candidates for clonal testing. The yearly populations often numbered several thousand and a recording of individual incompatible reactions in addition to quantitative assessments of each component of the compatible reaction type proved impractical. Consequently, the annual seedling populations were screened for general field resistance using two selection thresholds in place of standard categorical disease-scoring methods. This paper is presented as an 11-year case study of the effectiveness of the threshold selection methodology operating across both reaction types. Realized heritabilities resulting from the use of the selection thresholds are reported and compared to published heritability values for Melampsora leaf rust resistance. The functional relationship between selection intensity and changes in population rust liability - the trait or trait complex that determines quantitative variation in resistance - is developed in light of differences in infection-season precipitation rates.

\section{Methods}

The annual $P . \times$ generosa populations were developed by controlled hybridization of $P$. deltoides and $P$. trichocarpa. P. trichocarpa parents were chosen as mature phenotypes from natural alluvial and upland stands located west of the Cascade Mountains between $42^{\circ} 56^{\prime} \mathrm{N}$ latitude (South Umpqua River, Douglas County, Oregon) and $48^{\circ} 56^{\prime} \mathrm{N}$ latitude (Nooksack River, Whatcom County, Washington). The average age of the P. trichocarpa parents was 37 years and ranged from 14 to 77 years. $P$. deltoides parents were mainly selected from an extensive varietal collection at Fitler, Mississippi, established in 1980 by the U. S. Forest Service with genotypes from alluvial stands within the lower Mississippi River Valley between Baton Rouge, Louisiana, $\left(30^{\circ} 36^{\prime} \mathrm{N}\right.$ latitude) and Memphis, Tennessee, ( $35^{\circ} 14^{\prime} \mathrm{N}$ latitude) (COOPER, 1980). The Fitler collection also included a lesser number of $P$. deltoides representatives from the Texas Forest Service's sampling of the Brazos and Trinity Rivers and Oklahoma State University's sampling of the Red River between $30^{\circ} 03^{\prime} \mathrm{N}$ and 
$35^{\circ} 57^{\prime} N$. Rust resistance was not considered when choosing parents in either species; resistance was difficult to gauge in the mature natural $P$. trichocarpa stands, while rust pressure was typically too light in the $P$. deltoides Fitler clone tests for meaningful evaluations. Reciprocal crosses (i.e. P. deltoides $\times$ P.trichocarpa and P.trichocarpa $\times$ P.deltoides) were made yearly between 1991-2001 within a glasshouse at Camas, Washington, using the procedures described by STANTON and VILLAR (1996). Seventy-two (72) hybrid crosses were attempted in most years using two series of four disconnected, mostly $3 \times 3$ factorials, one for each reciprocal cross type. Hybrid offspring were recovered from 164 $P$. deltoides and 194 P. trichocarpa parents over the 11 years and, although repeated parental samples were taken in some years, each year's population had a unique set of full-sibs. Containerized seedlings were propagated in the Camas glasshouse during the same year of breeding.

Each of the 11 populations was screened in its second year for rust resistance to identify a subset of seedling phenotypes for replicated clonal field trialing conducted during a third year. Both seedling and clonal evaluations were conducted at Westport, Oregon, $\left(46^{\circ} 08^{\prime} \mathrm{N}\right.$, $123^{\circ} 22^{\prime} \mathrm{W}$ ) on the lower Columbia River floodplain. The soil there is deep, moderately well drained with a loamsilt loam surface overlaying a sandy loam to fine sand horizon. Precipitation during the July through October period of urediniospore dispersal averaged $217 \mathrm{~mm}$ from 1935-1995 as reported by a Clatskanie, Oregon, weather station located approximately $14 \mathrm{~km}$ from Westport. Maximum and minimum daily temperatures over the July through October period averaged $20.7^{\circ} \mathrm{C}$ and $9.9^{\circ} \mathrm{C}$, respectively. Daily temperature and precipitation rates during the four month infection season were recorded at the Clatskanie station throughout the case study. Each of the Westport seedling nurseries was established at a $0.6 \times 0.9 \mathrm{~m}$ spacing in unreplicated family row plots. Each of the clonal trials was planted at a $1.8 \times 1.8 \mathrm{~m}$ spacing using a completely randomized design of eight ramets per genotype propagated as containerized leafy rooted cuttings grown in the Camas glasshouse from seven-to-10 cm long hardwood cuttings taken from selected ortets in the Westport nursery. Survival resulting from this method of clonal propagation was uniformly high, averaging $96 \%$ for all 11 populations and ranging between 91-99\%.

The extent of rust severity on the seedling and clonal populations was assessed as a threshold character using a modified version of SCHREINER's (1959) technique, with three categories based upon the amount of leaf area bearing uredinia and the extent of leaf chlorosis and necrosis throughout the crown. Assessments were based on all leaves with the exception of newly formed ones that are known to be inherently resistant (HEATHER et al., 1980; JoHnsON and YoNG, 2005). The three categories were defined as follows:

High resistance - A few uredinia on leaves throughout no more than $20 \%$ of the crown. No chlorosis.

Moderate resistance -20 to $33 \%$ of the crown with readily observable uredinia covering approximately 20 to $30 \%$ of the surface of individual leaves with easily observed chlorotic, but no necrotic, tissue.

Low resistance - More than $33 \%$ of crown exhibiting extensive uredinia and chlorotic tissue covering individual leaves. Necrotic leaves often present with some defoliation.

Phenotyping of each annual population's one-year-old seedling nursery and one-year-old clonal field trial was conducted in successive years, and scheduled to reasonably ensure that the two were phenotyped at approximately the same level of disease severity. All assessments took place between September 27 and October 18 coinciding with the recommended opportune timing of rust evaluations for the region (WANG and VAN DER KAMP, 1992; NewCombe et al., 1994). Seedling phenotypes chosen for clonal trialing came solely from the high and moderate resistance categories. Directional mass selections were made from all families with acceptable phenotypes; the tallest seedlings were selected from those families in which an overabundance of acceptable ones was found. The assignment of genotypes to a resistance category at the clonal stage was based on the mode of each genotype's eight ramets; where a mode was not identified, ramets were revisited to ascertain the appropriate resistance category. As an initial check on the efficacy of the threshold selection procedure, a subset of seedlings from the low resistance category from the first population (i.e. 1991) was advanced to clonal testing as a control treatment along with their counterparts from the moderate and high categories. This will be referred to as the preliminary, bi-directional selection test of the efficacy of the threshold procedure.

The case study utilized FALCONER's (1981) procedure for the selection of threshold characteristics in which the moderate and high resistance categories defined two selection thresholds, I and II, respectively. Threshold I marked the transition between necrotic and chlorotic tissue while threshold II marked the transition to a chlorosis-free symptom though not necessarily implying the transition from the compatible to the incompatible reaction type. The incidence of the population exceeding threshold I (i.e. the cumulative percentage of genotypes in both the moderate and high resistance categories) and the incidence of those exceeding threshold II (high resistance) was recorded for each population's seedling nursery and clonal fields trials. A selection threshold unit (T.U.) was then calculated for each nursery and clone trial according to equation 1 (FALCONER, 1981):

$$
1 \text { T. U. }=\left(\mathrm{x}^{\prime \prime}-\mathrm{x}^{\prime}\right) \mathrm{S}
$$

where $x "$ and $x$ ' are incidences expressed in standard deviations ( $\mathrm{s}$ ) from a truncated normal distribution corresponding to the percentages of genotypes associated with selection thresholds II and I, respectively. The standard deviation of rust resistance (s) in the nurseries and clonal trials in threshold units was then determined by equation 2 (FALCONER, 1981):

$$
\mathrm{s}=\left[1 /\left(\mathrm{x}^{\prime}-\mathrm{x}^{\prime}\right)\right] \text { T. U. }
$$

Finally, the mean liability (m), equivalent to the mean expression of the underlying quantitative traits control- 
ling variation in rust phenotypes, was estimated for each of the annual populations at their seedling and clonal stages in standard deviation units above or below threshold I using equation 3 (FALCONER, 1981):

$$
\mathrm{m}=-\mathrm{x}^{\prime} \mathrm{s}
$$

The response to mass selection in the seedling nurseries undergoing directional selection was then determined for each year's population as the difference in both the mean liability and the standard deviation of rust resistance between the non-selected seedling and the selected clonal stages. The preliminary assessment of bi-directional selection in the 1991 population was based on comparing selection responses of seedlings at the clonal stage taken above threshold I (i.e. positive selection) with those taken from below (i.e. negative selection).

For the main portion of the study, the response to directional mass selection across all 10 populations was regressed on selection intensity and infection-season precipitation using the following quadratic equation:

$$
\mathrm{y}_{n}=\alpha+\beta_{i}(i)+\beta_{j}\left(i^{2}\right)+\beta_{k}(g)+\beta_{l}(i g)+\beta_{m}\left(i^{2} g\right)
$$

where $\mathrm{y}_{n}$ is the change in liability or standard deviation between the nursery and clonal field stages of the $n^{\text {th }}$ annual population, $i$ is selection intensity (i.e. the mean standard deviation of the proportion of the selected nursery seedlings residing above threshold $I$ in the nursery), and $g$ is the precipitation effect as represented by two groups of nursery populations coded as " 0 " or " 1 " for those grown during relatively dry and wet years, respectively.

The ratio of the selection response in mean liability to the intensity of selection was calculated for each population as an expression of realized heritability. Lastly, a chi-square test for independence between resistance cat- egory and test stage was conducted for each population to determine if mass selection from the upper nursery threshold led to a similarly superior expression of rust resistance at the clonal stage.

\section{Results}

\section{Effectiveness of Bi-directional Selection: 1991 Population}

Bi-directional selection within the 1991 population provided an initial indication that mass selection for rust resistance using the threshold approach could be effective (Table 1). When observed in the 1992 seedling nursery, $34 \%$ of the population's 774 genotypes exceeded threshold I - of which eight percent also exceeded threshold II - with the remainder, $66 \%$ falling below threshold I. The mean nursery liability and its standard deviation were -0.42 T.U. and 1.01 T. U., respectively. Subsets of 253 seedlings that were categorized above threshold I (i.e. the positive selection group) and 260 seedlings categorized below threshold I (i.e. the negative selection group) were then tested as clones in the 1993 field trial. There, only $10 \%$ of the negative selection group was found above threshold I and just four percent above threshold II; the group's mean liability and standard deviation were -2.45 T. U. and 1.94 T. U., respectively. In contrast, the 253 phenotypes of the positive selection group segregated with $53 \%$ of the clonal genotypes testing above threshold I and $12 \%$ above threshold II. The mean liability was 0.06 T.U. and the standard deviation was $0.80 \mathrm{~T}$. U. In view of the wide separation in liability between the positive and negative selection groups, bi-directional mass selection was judged to be effective in sorting among seedling rust phenotypes for the best subset for clonal evaluation. The effectiveness of directional threshold selection was then examined for the ensuing 10 nursery populations.

Table 1. - Change in liability and standard deviation of the $1991 P . \times$ generosa population undergoing bi-directional mass selection for Melampsora rust resistance.

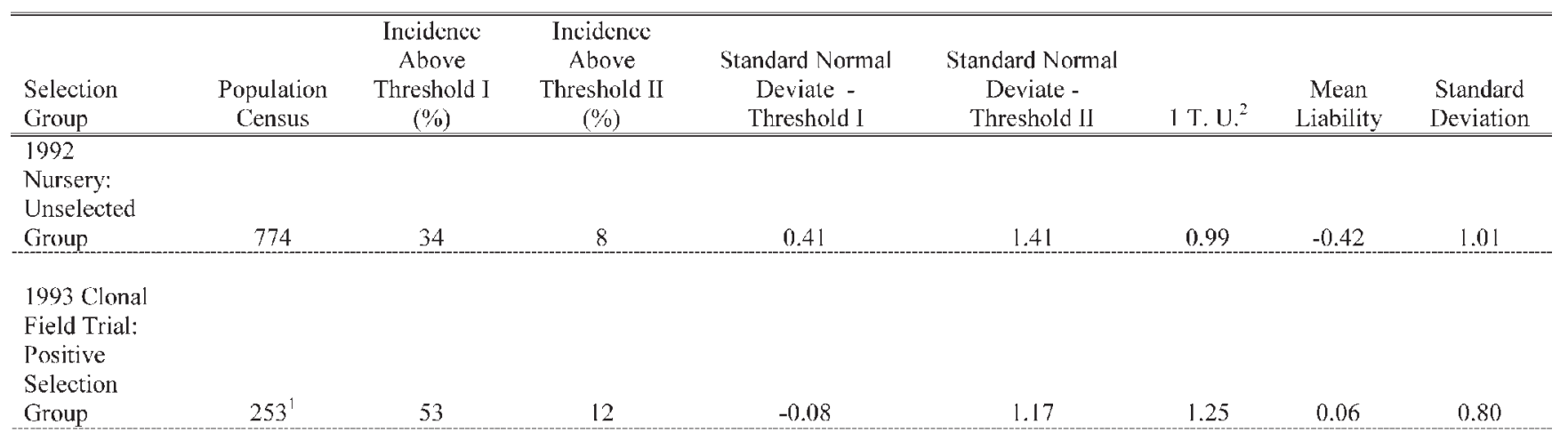

\section{Clonal}

Field Trial:

Negative

Selection

Group

$260^{1}$

10

4

1.26

1.77

0.51

$-2.45$

1.94

1 The sum of the number of clones of the 1993 field trial from the negative (260) and positive groups (253) does not equal the total of the nursery population (774) as not all nursery seedlings were cloned.

2 T. U. is a threshold unit of population rust liability as determined by the absolute difference between thresholds I and II expressed as standard deviations. 
Change in Population Structure Under Directional Selection: 1992-2001 Populations

The number of seedling phenotypes evaluated at the nursery stage averaged 1,403 per annual population, varying between 651 (1992 population) and 2,392 (1999 population) (Table 2). These represented 50 full-sib families on average, a quantity that varied from 31 (2000 population) to 61 families (1996 population). Yearly variation in nursery census and family number was principally a reflection of the programmatic emphasis placed on developing other inter-specific taxa during any given year, which necessitated a reduction in the mainline $P . \times$ generosa hybridization effort. Sizable variation in mean family size was consistently observed with standard deviations exceeding their means in nearly all years ( $136 \%$ mean coefficient of variation), the phenomenon typical of the pronounced variation in reproductive success in the $P . \times$ generosa taxon (STANTON, 2005). Averaged across the 10 nurseries, $13 \%$ of the seedling populations, or 183 out of 1,403 phenotypes, were advanced to clonal testing (Table 2 ). The yearly range in the percentage of seedlings undergoing clonal testing was $8-28 \%$. This was accompanied by a $36 \%$ reduction in the number of families, 32 versus 50. Similarly, a reduction in both the mean (i.e. 5.7 sibs versus 27.9 sibs) and the standard deviation in family size (i.e. 8.0 sibs versus 38.0 sibs) were caused by the selection of nursery phenotypes for clonal testing.

\section{Change in Rust Distribution Under Directional Selection: 1992-2001 Populations}

The mean incidence of phenotypes in the nurseries at thresholds I and II was $47 \%$ and $11 \%$, respectively (Table 3). When averaged across the 10 populations, threshold I was situated at 0.08 T. U. above the nursery mean while threshold II was located at 1.33 T. U. (Table 3 ). Threshold I incidences varied from highs of 59-61\% (1993, 1997 and 1998 populations) to lows of $32-38 \%$ (1992, 1994, 1996, and 1999 populations). Correspondingly, threshold II incidences were highest in the 1993 and 1998 populations (26 and $16 \%$, respectively) and lowest in the 1996 and 1999 populations (4 and 2\%, respectively).

Liability averaged -0.06 T.U. over all 10 nurseries ranging from $-0.41 \mathrm{~T}$.U. (1994 population) to $0.28 \mathrm{~T}$. U. (1993 population) (Table 4). It was positive in the 1993, 1997, 1998, and 2000 populations; a negative threshold I for each suggested less rust exposure compared with the other six populations (cf. Tables 3 and 4). The standard deviation of nursery rust averaged $0.83 \mathrm{~T}$. U. ranging from a low of 0.63 T.U. (1999 population) to a high of 1.15 T.U. (1994 population). Liability and its standard deviation were not associated $(r=-0.04)$. Similarly, neither variation in nursery liability nor its standard deviation was associated with any of the measures of population structure (i.e. census, number of families, family size, variation in family size). The lone associate of liability was the amount of precipitation experienced during the July through October period of urediniospore dispersal and infection that exhibited a marked and substantial contrast between two groupings of populations. Relatively high rates of infection-season precipitation were received during four consecutive years, 1993 through 1996, when mean and minimum respective precipitation levels of $298 \mathrm{~mm}$ and $217 \mathrm{~mm}$ were recorded (data not shown). In contrast, there were six years of lower precipitation, 1992 and 1997 through 2001, when a mean of $120 \mathrm{~mm}$ and a maximum of $186 \mathrm{~mm}$ were recorded. Neither the maximum nor the minimum daily temperature during the infection season exhibited similar variation over the 10 years (e.g. coefficients of variation of 3.2 and $8.2 \%$, respectively, compared with a $56 \%$ coefficient of variation for precipitation). The liability of the nursery seedling populations observed during the four consecutive years of highest rainfall was six fold lower than the mean liability of those nurseries observed during the other six drier years $(-0.12$ versus -0.02), an indication that increased precipitation and, perhaps, higher humidity and prolonged leaf wetness may have resulted in higher overall levels of rust (KRZAN, 1980).

Selection intensity associated with the truncation of the nursery populations at threshold I averaged 0.860 , ranging from a low of 0.629 (1998 population) to a high of 1.118 (1999 population) (Table 4). Selection intensity, as expected, was highly correlated with threshold I incidence $(r=-0.99)$. But since the proportion of the nursery populations moved to the clonal testing stage was a nonconstant sampling of phenotypes from above threshold I, a weak linear correlation was found between selection intensity and the percentage of genotypes cloned for field testing $(\mathrm{r}=0.29)$. The distribution of resistance categories was clearly changed at the clonal stage. There, $81 \%$ of the population on average was classified above

Table 2. - Change in structure of $P . \times$ generosa populations undergoing directional mass selection for Melampsora rust resistance.

\begin{tabular}{|c|c|c|c|c|c|c|c|c|}
\hline & \multicolumn{4}{|c|}{ Scedling Nursery } & \multicolumn{4}{|c|}{ Clonal Testing } \\
\hline Population & $\begin{array}{l}\text { Census of } \\
\text { Genotypes }\end{array}$ & $\begin{array}{c}\text { Number of } \\
\text { Families }\end{array}$ & $\begin{array}{c}\text { Mean } \\
\text { Family Size }\end{array}$ & $\begin{array}{c}\text { Standard Deviation } \\
\text { Family Size }\end{array}$ & $\begin{array}{l}\text { Census of } \\
\text { Genotypes }\end{array}$ & $\begin{array}{l}\text { Number of } \\
\text { Families }\end{array}$ & $\begin{array}{c}\text { Mean } \\
\text { Family Size }\end{array}$ & $\begin{array}{c}\text { Standard Deviation } \\
\text { Family Size }\end{array}$ \\
\hline 1992 & 651 & 59 & 11.0 & 11.2 & 156 & 38 & 4.1 & 5.5 \\
\hline 1993 & 1,877 & 49 & 38.3 & 62.4 & 219 & 39 & 5.6 & 8.9 \\
\hline 1994 & 2,145 & 52 & 41.3 & 61.4 & 204 & 28 & 7.3 & 12.7 \\
\hline 1995 & 954 & 54 & 17.7 & 41.9 & 160 & 30 & 5.3 & 6.3 \\
\hline 1996 & 981 & 61 & 16.1 & 20.1 & 158 & 38 & 4.2 & 3.3 \\
\hline 1997 & 982 & 44 & 22.3 & 45.6 & 278 & 31 & 9.0 & 17.2 \\
\hline 1998 & 2,293 & 55 & 41.7 & 47.9 & 185 & 32 & 5.8 & 6.6 \\
\hline 1999 & 2,392 & 56 & 42.7 & 49.0 & 303 & 37 & 8.2 & 12.5 \\
\hline 2000 & 758 & 31 & 24.5 & 18.8 & 63 & 15 & 4.2 & 3.3 \\
\hline 2001 & 998 & 43 & 23.2 & 22.1 & 100 & 28 & 3.6 & 3.9 \\
\hline Mean & 1,403 & 50 & 27.9 & 38.0 & 183 & 32 & 5.7 & 8.0 \\
\hline
\end{tabular}


Table 3. - Incidences and threshold levels for seedling nurseries and clonal trials of $10 P . \times$ generosa populations undergoing directional selection for Melampsora leaf rust resistance.

\begin{tabular}{|c|c|c|c|c|c|c|c|c|}
\hline & \multicolumn{4}{|c|}{ Sccdling Nursery } & \multicolumn{4}{|c|}{ Clonal Testing } \\
\hline Population & $\begin{array}{l}\text { Incidence } \\
\text { Above } \\
\text { Thrcshold I } \\
(\%)\end{array}$ & $\begin{array}{l}\text { Incidence Above } \\
\text { Threshold II (\%) }\end{array}$ & $\begin{array}{c}\text { Threshold I } \\
\text { (T.U.) }\end{array}$ & $\begin{array}{c}\text { Threshold II } \\
\text { (T.U.) }\end{array}$ & $\begin{array}{c}\text { Incidence } \\
\text { Above } \\
\text { Threshold I } \\
(\%)\end{array}$ & $\begin{array}{c}\text { Incidence } \\
\text { Above } \\
\text { Threshold II } \\
(\%)\end{array}$ & $\begin{array}{c}\text { Threshold I } \\
\text { (T.U.) }\end{array}$ & $\begin{array}{c}\text { Threshold II } \\
\text { (T.U.) }\end{array}$ \\
\hline 1992 & 38 & 8 & 0.31 & 1.41 & 72 & 13 & -0.58 & 1.13 \\
\hline 1993 & 60 & 26 & -0.25 & 0.64 & 57 & 14 & -0.18 & 1.08 \\
\hline 1994 & 36 & 11 & 0.36 & 1.23 & 88 & 34 & -1.17 & 0.41 \\
\hline 1995 & 43 & 8 & 0.18 & 1.41 & 62 & 3 & -0.31 & 1.88 \\
\hline 1996 & 37 & 4 & 0.33 & 1.75 & 94 & 26 & -1.55 & 0.64 \\
\hline 1997 & 59 & 12 & -0.23 & 1.17 & 89 & 22 & -1.23 & 0.77 \\
\hline 1998 & 61 & 16 & -0.28 & 0.99 & 96 & 33 & -1.75 & 0.44 \\
\hline 1999 & 32 & 2 & 0.47 & 2.05 & 91 & 13 & -1.34 & 1.13 \\
\hline 2000 & 54 & 11 & -0.09 & 1.20 & 81 & 19 & -0.88 & 0.88 \\
\hline $200 \mathrm{l}$ & 49 & 7 & 0.02 & 1.49 & 82 & 16 & -0.92 & 0.99 \\
\hline Mean & 47 & 11 & 0.08 & 1.33 & 81 & 19 & -0.99 & 0.94 \\
\hline
\end{tabular}

Table 4. - Changes in liability and standard deviation and realized heritability of $10 P . \times$ generosa populations undergoing directional selection for Melampsora leaf rust resistance.

\begin{tabular}{|c|c|c|c|c|c|c|c|c|}
\hline & \multicolumn{3}{|c|}{ Sccdling Nurscry } & \multicolumn{5}{|c|}{ Clonal Testing } \\
\hline Population & $\begin{array}{c}\text { Liability } \\
\text { (m) } \\
\text { T.U. }\end{array}$ & $\begin{array}{c}\text { Std. Dev. } \\
\text { (s) } \\
\text { T.U. }\end{array}$ & $\begin{array}{c}\text { Selection } \\
\text { Intensity } \\
(i)\end{array}$ & $\begin{array}{c}\text { Liability } \\
\text { (m) } \\
\text { T.U. }\end{array}$ & $\begin{array}{c}\text { Std. Dev. } \\
\text { (s) } \\
\text { T.U. }\end{array}$ & $\begin{array}{c}\text { Change in } \\
\text { Liability } \\
(\Delta \mathrm{m}) \\
\text { T.U. }\end{array}$ & $\begin{array}{c}\text { Change in } \\
\text { Std. Dev. } \\
(\Delta s) \\
\text { T.U. }\end{array}$ & $\begin{array}{c}\text { Realized } \\
\text { Heritability }\end{array}$ \\
\hline 1992 & -0.28 & 0.91 & 1.002 & 0.34 & 0.59 & 0.62 & -0.32 & 0.62 \\
\hline 1993 & 0.28 & 1.12 & 0.644 & 0.14 & 0.80 & -0.14 & -0.32 & -0.22 \\
\hline 1994 & -0.41 & 1.15 & 1.039 & 0.74 & 0.63 & 1.15 & -0.52 & 1.11 \\
\hline 1995 & -0.14 & 0.81 & 0.913 & 0.14 & 0.46 & 0.28 & -0.36 & 0.31 \\
\hline 1996 & -0.23 & 0.70 & 1.020 & 0.71 & 0.45 & 0.94 & -0.25 & 0.92 \\
\hline 1997 & 0.16 & 0.71 & 0.659 & 0.61 & 0.50 & 0.45 & -0.21 & 0.69 \\
\hline 1998 & 0.22 & 0.79 & 0.629 & 0.80 & 0.46 & 0.58 & -0.33 & 0.92 \\
\hline 1999 & -0.29 & 0.63 & 1.118 & 0.54 & 0.41 & 0.84 & -0.23 & 0.75 \\
\hline 2000 & 0.07 & 0.77 & 0.741 & 0.50 & 0.57 & 0.43 & -0.21 & 0.58 \\
\hline 2001 & -0.01 & 0.68 & 0.814 & 0.48 & 0.52 & 0.49 & -0.15 & 0.60 \\
\hline Mean & -0.06 & 0.83 & 0.860 & 0.50 & 0.54 & 0.56 & -0.29 & 0.63 \\
\hline
\end{tabular}

${ }^{1}$ Ratio of the change in liability to selection intensity.

threshold I relative to the comparable incidence in the nursery (47\%) (Table 3). In just one case (1993 population) was the threshold I incidence at the clonal stage less than that observed in the corresponding nursery. Likewise, threshold II incidences increased nearly twofold from $11 \%$ to $19 \%$ between the nursery and the clonal stages. Because of these consistent changes in incidences, concomitant changes in liability under selection were positive in all but the 1993 population: liability increased over nine fold from $-0.06 \mathrm{~T}$. U. in the unselected nursery populations to $0.50 \mathrm{~T}$. U. in the clonal trials of selected genotypes (Table 4). The selection effect was also manifested by a consistent reduction in standard deviation in rust resistance observed in all populations between the seedling nursery (mean of 0.83 T.U.) and the clonal (mean of 0.54 T. U.) stages (Table 4).

\section{The Effect of Selection Intensity on Change in Liability}

The change in liability was strongly related by polynomial regression to selection intensity and the grouping of populations based on infection-season precipitation (Table 5). The adjusted coefficient of determination and the regression standard error for the full model were $98.2 \%$ and $8.31 \%$, respectively. Both linear and quadratic components of the selection intensity effect were significant at probability levels of 0.023 and 0.016 , respec- tively; the group precipitation effect was significant at a probability level of 0.034 (Table 5). The linear-by-group interaction was significant at the 0.013 probability level, as was the quadratic-by-group interaction at a probability level of 0.007 .

The vertices of the respective polynomial functions occurred at selection intensities of 0.75 (dry years) and 0.70 (wet years). The difference in the quadratic coefficient between the two population groups (13.20 versus 3.43 T.U.) indicated that the change in liability of populations undergoing rust evaluation during the wet years was much more responsive to increases in selection intensity above the vertex (Figure 1). Realized heritability, the change in liability expressed as a ratio to the selection intensity exercised in nursery selection, averaged 0.63 over all 10 populations. It was negative in one instance (1993) and exceeded unity in a second (1994), but otherwise varied between 0.31 and 0.92 (Table 4). It also tended to increase with heavier nursery rust exposure as measured by mean liability $(\mathrm{r}=-0.52)$.

\section{Difference in Selection Response Between Resistance Categories}

The overall chi-square test of independence of rust categorization in nursery and clonal field trials was 
highly significant for populations in aggregate; individual chi-square tests were significant for all but two populations (1995 and 2000) (Table 6). Averaged across populations, the percentage of phenotypes selected from the high resistance category in the nursery showed a preferential allocation of clonal genotypes in the high resistance category compared to the clonal distribution from the moderate category of nursery phenotypes. However,

Table 5. - Analysis of variance for polynomial regression of the change in liability $(\Delta \mathrm{m})$ on selection intensity and populations grouped by infection-season precipitation during $P . \times$ generosa nursery evaluation for Melampsora leaf rust resistance.

\begin{tabular}{|l|c|c|c|}
\hline Regression Model Term & Degrees of Fredom & T-Value & P-Value \\
\hline Selection intensity $(i)$ & 1 & & \\
$\quad$ Linear & 1 & -3.58 & 0.023 \\
$\quad$ Quadratic & 1 & 4.01 & 0.016 \\
Population Group $(\mathrm{g})$ & 1 & 3.18 & 0.034 \\
$i \times g$ interaction & 1 & -4.31 & 0.013 \\
$\quad$ Linear & 4 & 5.20 & 0.007 \\
$\quad$ Quadratic & & & \\
Error & & & \\
\hline
\end{tabular}

The full regression model is: $\Delta \mathrm{m}=2.54+-5.34(i)+3.43(i)^{2}+4.11(\mathrm{~g})+-13.72(i \mathrm{~g})+9.81\left(i^{2} \mathrm{~g}\right)$.

The regression equation for the populations when undergoing rust evaluation during the comparatively drier years (i. e. $\mathrm{g}=0$ ) is: $\Delta \mathrm{m}=2.54+-5.34(i)+3.43(i)^{2}$.

Conversely, the quadratic equation for the populations that underwent evaluation during the years of higher rainfall (i. e. $\mathrm{g}=1$ ) is: $\Delta \mathrm{m}=6.55+-19.1(i)+13.20(i)^{2}$.
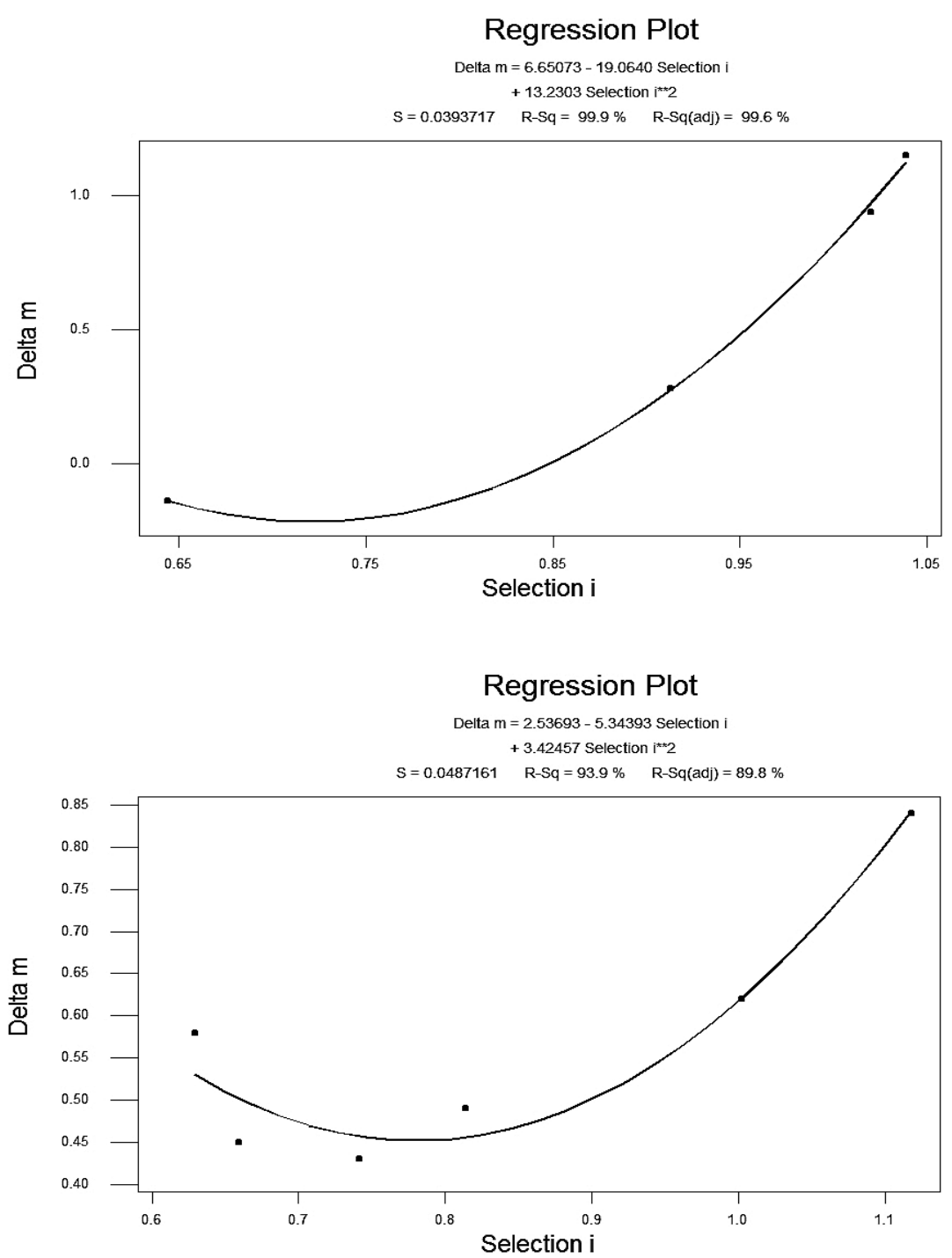

Figure 1. - Regression of the change in liability as a function of selection intensity - Nurseries evaluated during dry years (upper graph) and during wet years (lower graph). 
Table 6. - Chi-square test of independence of resistance categories at the seedling nursery and clonal trial stages (in percent) of $P . \times$ generosa populations undergoing directional selection for Melampsora leaf rust resistance.

\begin{tabular}{|c|c|c|c|c|c|}
\hline & & \multicolumn{3}{|c|}{ Clone Test } & \multirow[b]{2}{*}{ Chi-Square } \\
\hline Population & Nursery & High & Moderate & Low & \\
\hline \multirow[t]{2}{*}{1992} & High & 27 & 70 & 3 & \\
\hline & Moderate & 10 & 57 & 33 & $14.1^{\prime \prime}$ \\
\hline \multirow[t]{2}{*}{1993} & High & 22 & 35 & 43 & \\
\hline & Moderate & 4 & 52 & 44 & $15.8^{\star}$ \\
\hline \multirow[t]{2}{*}{1994} & High & 56 & 40 & 4 & \\
\hline & Moderate & 19 & 63 & 18 & $32.4^{*}$ \\
\hline \multirow[t]{2}{*}{1995} & High & 9 & 52 & 39 & \\
\hline & Moderate & 2 & 61 & 38 & 5.1 \\
\hline \multirow[t]{2}{*}{1996} & High & 64 & 36 & 0 & \\
\hline & Moderate & 20 & 74 & 7 & $19.3^{*}$ \\
\hline \multirow[t]{2}{*}{1997} & High & 49 & 51 & 0 & \\
\hline & Moderate & 12 & 73 & 15 & $50.9^{*}$ \\
\hline \multirow[t]{2}{*}{1998} & High & 70 & 30 & 0 & \\
\hline & Moderate & 23 & 72 & 6 & $32.1^{*}$ \\
\hline \multirow[t]{2}{*}{1999} & High & 48 & 48 & 4 & \\
\hline & Moderate & 10 & 79 & 10 & $26.1^{*}$ \\
\hline \multirow[t]{2}{*}{2000} & High & 29 & 61 & 11 & \\
\hline & Moderate & 11 & 63 & 26 & 4.3 \\
\hline \multirow[t]{2}{*}{2001} & High & 48 & 52 & 0 & \\
\hline & Moderate & 8 & 70 & 23 & $22.1^{*}$ \\
\hline \multirow[t]{2}{*}{ Mean } & High & 42 & 48 & 10 & \\
\hline & Moderate & 12 & 66 & 22 & $25.04^{*}$ \\
\hline
\end{tabular}

* Chi-Square significant at the 0.001 level of probability with two degrees of freedom.

the significant association between resistance categories at the two stages notwithstanding, both of the resistance categories at the nursery stage typically were tied to considerable segregation at the clonal stage.

\section{Discussion}

With the sole exception of the 1993 population, consistent improvements in mean rust liability coupled with decreases in standard deviation were indicative of the success of mass selection for rust resistance using a threshold approach in $P . \times$ generosa seedling populations. However, this conclusion should be considered in light of two potentially confounding environmental effects: (1) the more closely-spaced nursery plantings with localized humidity and leaf surface moisture may have promoted rust infection compared with the more widely-spaced clonal trials and (2) non-selected and selected representatives of each population were evaluated in successive years under different weather conditions despite best efforts to evaluate each at approximately the same stage of disease development. Yet when conducted during the same year and in the same plot, bi-directional selection of the 1991 population showed that changes in liability (but not standard deviation) were as expected for positive and negative selection. This supported the findings of directional selection and substantiated published reports of the effectiveness of mass selection for rust resistance in one-year-old nurseries (RAJORA et al., 1994).

The thresholds employed in this study were unconventional, because they were not defined by phenotypes that only appear when an underlying quantitative trait - uredinia size and density, latent period, sporulation frequency - penetrates to a recognizable phenotype at a set level of gene expression. Instead, selection was based on an integrated trait, whole-tree photosynthetic area, using thresholds set to identifiable points in a continuum of phenotypes corresponding to the appearance of reasonably healthy, chlorotic, and necrotic tissue. But as variation in the quantitative components of the compatible reaction type in laboratory assays has been associated with field resistance in a number of studies (HAMELIN et al., 1994; LeGionnet et al., 1999), the method used in the case study should work well with $P$. $\times$ generosa improvement programs. This is important, because threshold selection on the basis of the quantitative components of resistance would be unworkable if attempted on a scale as large as the populations observed in this study over successive years. Moreover, recent research indicates that selection for individual components of quantitative resistance (e.g. uredinium size) in the $P . \times$ generosa-Melampsora pathosystem may not protect against a range of rust isolates that is normally expected of host genotypes exhibiting rate-reducing responses (DowkIw et al., 2010). Selection based on integrated rust phenotypes may lead to more durable resistance since it combines all components of the quantitative resistance mechanism into a composite resistance trait that is more challenging to evolving pathogen variation.

The goal of the Pacific Northwest industrial $P . \times$ generosa improvement program has always been the selection and deployment of rust-tolerant genotypes that are temporally and spatially buffered against epidemics arising from the pool of pathogen variation in the lower 
Columbia River Valley (NEwCOMBE et al., 2001). Implicit in how thresholds were established and used is the assumption of a single mechanism of rust resistance or one of highly integrated quantitative-qualitative mechanisms. Although both oligogenic and polygenic resistance systems operate in the Populus-Melampsora patho-system (PICHOT and TeIssier DU CROS, 1993a; Pichot and Teissier DU CROs, 1993b), the two appear to act interdependently in the response of the $P . \times$ generosa taxon to major Melampsora taxa. NEwComBE et al. (1996) and NewCombe (1998) have shown that the hypersensitive response to $M$. medusae in $P . \times$ generosa is governed by a single dominant gene $(M m d 1)$ that is linked with the expression of uredinial diameter and density as components of the same infection type. Similarly, the major genes that determine resistance to $M$. $\times$ columbiana in $P . \times$ generosa $(M \times c 1$ and $M \times c 2)$ are also associated with quantitative traits of uredinial density and latent period (NEWCOMBE et al., 2001). Finally in $M$. larici-populina, the expression of major gene resistance in $P . \times$ generosa is interactive with the components of quantitative resistance (DowkIW and BASTIEN, 2004; DowKIW and BASTIEN, 2007); the phenomenon may result from the close linkage of major genes and quantitative gene systems (JORGE et al., 2005). Similar evidence for an integrated resistance mechanism has been found in the related Populus inter-specific taxon, $P$. $\times$ canadensis, where the expression of a single dominant gene (MER) conferring resistance to M. larici-populina is modified by a set of closely linked genes manifesting quantitative variation in resistance (CERVERA et al., 1996). The assignment of $P$. deltoides genotypes to either resistant or susceptible $M$. medusae rust infection classes is influenced by modifying genes controlling latent periods and sporulation rates (PRAKASH and HEATHER, 1986). Furthermore, Boyle et al. (2010) have shown that defensive chemical responses at the molecular level are common to the qualitative and quantitative resistance mechanisms. Thus, it does not seem unreasonable to use selection thresholds that encompass the entire range of resistance phenotypes from the hypersensitive response of the incompatible reaction type to the rate-reducing features of the compatible reaction type.

The lack of a selection response in population liability or standard deviation to the proportion of the nursery populations selected from clonal tests does not discount the validity of the approach but does speak to the imprecision of threshold-based phenotyping: all selected individuals within resistance categories were considered as uniformly resistant because finer levels of resistance were not discernable (FALCONER, 1981). Increasing the ratio of selections from the high resistance category would be, nonetheless, expected to improve liability as shown by the chi-square analysis. However, the magnitude of genotypes that did not register as clones within the same resistance category as their seedling ortets indicates the strength of environmental influences on the expression of rust phenotypes. Within this context, the quadratic interaction between selection intensity and population grouping suggests at least one variable precipitation - that could be manipulated to improve the selection response. For example, disease pressure could be increased through the interplanting of highly susceptible genotypes to increase inoculum - as is the routine in wheat breeding (M. DIETERS, personal communication) - combined with periodic application of overhead irrigation to provide conditions conducive to infection. This could increase selection intensity well above 0.70-0.75 standard deviations and lead to more reliable phenotypic selections. Indeed, realized heritability increased with higher infection levels at the nursery stage; the same observation has been reported for mass selection in rust infection of slash pine ( $P$. elliottii Engelm. (HoDGE et al., 1990). Increasing the incidence of disease has been associated with improved selection efficiency for fusiform rust resistance using the threshold approach in slash pine (DIETERS et al., 1996).

Realized heritability across the 10 populations (0.63) is lower than most published estimates of broad sense heritability for Melampsora field resistance, which have approached 0.90 (JoKELA, 1966; THEILGES and ADAMS, 1975). Heritabilities from the literature are, however, frequently based on the variance analysis of categorical data treated as a continuously variable trait, whereas the case study is based on the analysis of a discrete variable. Indeed, the difference in the way categorical data are analyzed - qualitative versus quantitative methods - may affect heritability estimates. YANG et al. (1998) reported that heritability estimates should be less when treated as a threshold trait, compared with assessment based on a continuously varying trait. Yet, GALLO at al. (1985) and GULLBERG and RYTTMAN (1993) argued that the analysis of categorical data describing Melampsora resistance using the analysis of variance technique is appropriate with a moderately large number of resistance classes and transformation of the data to meet the assumption of normality.

\section{Conclusion}

Clonal populations formed by the truncation of seedling populations using selection thresholds based on whole-tree phenotypes of Melampsora leaf rust infection will lead to heightened levels of rust resistance and more uniform distributions, thereby facilitating selection for additional traits during clonally replicated testing. However, realized heritabilities were, on average, moderate in size and varied across populations; this finding, combined with the sizable segregation of genotypes from the high and moderate resistance categories, implies that the suitability of mass selection in sub-setting populations cannot substitute for the identification of individual clonal varieties for commercial use. Thus the case study focuses on the initial evaluation and truncation of seedling populations in forming subsets of phenotypes for continued testing as clonal replicates. Since realized heritabilities were not affected by the size and structure of the nursery population, non-recurrent $\mathrm{F}_{1} P . \times$ generosa hybridization programs can rely on finding sufficient numbers of genotypes for clonal testing if using populations roughly comparable to the ones that characterized the case study (i.e. 50 families composed of a mean of 25 siblings each). By exploiting factors con- 
ducive to infection and subsequent disease development it is possible to improve response in the seedling populations. Following clonal evaluation, individual varietal selections should be field tested across multiple sites to increase exposure to a range of pathogen genotypes and environmental conditions to identify those of inherent durable resistance.

\section{Acknowledgement}

I gratefully acknowledge the reviews of MARK J. DiETERS, The University of Queensland, George Newcombe, University of Idaho, and GLEN R. STANOsz, University of Wisconsin and their comments on an earlier draft of the manuscript.

\section{References}

Boyle, B., V. Levee, L.-P. Hamel, M.-C. Nicole and A. SEQUiN (2010): Molecular and histochemical characterisation of two distinct poplar Melampsora leaf rust pathosystems. Plant Biology 12: 364-376.

Cervera, M. T., J. Gusmao, M. Steenackers, J. Peleman, V. Storme, A. Vanden Broeck, M. Van Montagu and W. BOERJAN (1996): Identification of AFLP molecular markers for resistance against Melampsora larici-populina in Populus. Theoretical and Applied Genetics 93: 733-737.

Chiba, S. and Y. NAGata (1972): Rust resistance and growth of Populus maximowiczii clones selected from the progenies of intraspecific hybridization, pp. c-6 (V) 1-7. In: Proceedings of the Joint Symposia for the Advancement of Forest Tree Breeding, IUFRO and The Society for the Advancement of Breeding Researches in Asia and Oceania, Tokyo, Japan.

Cooper, D. T. (1980): Study Plan: Cooperative Cottonwood Advanced Clonal Tests. U. S. Department of Agriculture Southern Forest Experiment Station FS-SO-1402-1.19: $6 \mathrm{pp}$.

Dieters, M. J., G. R. HodGe and T. L. White (1996): Genetic parameter estimates for resistance to rust (Cronartium quercuum) infection from full-sib tests of slash pine (Pinus elliottii) modelled as functions of rust incidence. Silvae Genetica 45: 235-242.

Dowkiw, A. and C. BASTIEN (2004): Characterization of two major genetic factors controlling quantitative resistance to Melampsora larici-populina leaf rust in hybrid poplars: strain specificity, field expression, combined effects, and relationship with a defeated qualitative resistance gene. Phytopathology 94: 1358-1367.

Dowkiw, A. and C. BASTIEN (2007): Presence of defeated qualitative resistance genes frequently has major impact on quantitative resistance to Melampsora laricipopulina leaf rust in $P$. $\times$ interamericana hybrid poplars. Tree Genetics and Genomes 3: 261-274.

Dowkiw, A., E. VoISIN and C. BASTIEN (2010): Potential of Eurasian poplar rust to overcome a major quantitative resistance factor. Plant Pathology 59: 523-534.

FALCONER, D. S. (1981): Introduction to quantitative genetics. Longman Scientific and Technical, New York.

Gallo, L. A., B. R. Stephan and D. KRUSChe (1985): Genetic variation of Melampsora leaf rust resistance in progenies of crossings between and within Populus tremula and P. tremuloides clones. Silvae Genetica 34: 208-214.
Gullberg, U. and H. RYTTMAN (1993): Genetics of field resistance to Melampsora in Salix viminalis. European Journal of Forest Pathology 23: 75-84.

Hamelin, R. C., R. S. FerRiss, L. Shain and B. A. Thielges (1994): Prediction of poplar leaf rust epidemics from a leaf-disk assay. Canadian Journal of Forest Research 24: 2085-2088.

HeAther, W. A. and M. ChandRAsheKar (1982): Evolutionary, epidemiological and ecological implications of forms of resistance in Populus spp. to Melampsora leaf rust. Australian Forest Research 12: 231-244.

Heather, W. A., J. K. Sharma and A. G. Miller (1980): Physiologic specialization in Melampsora larici populina Kleb. on clones of poplar demonstrating partial resistance to leaf rust. Australian Forest Research 10: $125-131$.

Hodge, G. R., R. A. Schmidt and T. L. White (1990): Substantial realized gains from mass selection of fusiform rust-free trees in highly infected stands of slash pine. Southern Journal of Applied Forestry 14: 143-146.

HubBEs, M. (1979): Some important diseases of poplars, pp. 18-1-18-6. In: Poplar research, management and utilization in Canada, edited by D. C. F. FAYLE, L. Zsuffa and H. W. ANDERson, Forest Research Information Paper No. 102, Ontario Ministry of Natural Resources, Brockville, Ontario.

Johnson, J. D. and Y. KIM (2005): The role of leaf chemistry in Melampsora medusae infection of hybrid poplar: effects of leaf development and fungicide treatment. Canadian Journal of Forest Research 35: 763-771.

JoKELA, J. J. (1966): Incidence and heritability of Melampsora rust in Populus deltoides Bartr., pp. 111-117. In: Breeding pest-resistant trees, edited by H. D. Gerhold, E. J. Schreiner, R. E. McDermott and J. A. Winieski, Pergamon Press, New York.

Jorge, V., A. Dowkiw, P. FAivre-RAmpant and C. Bastien (2005): Genetic architecture of qualitative and quantitative Melampsora larici-populina leaf rust resistance in hybrid poplar: genetic mapping and QTL detection. New Phytologist 167: 113-127.

KRZAN, Z. (1980): Effect of climatic factors on development of the disease caused by Melampsora larici-populina. Folia Forestalia 422: 10-13.

Lefevre, F., C. Pichot and J. Pinon (1994): Intra- and interspecific inheritance of some components of the resistance to leaf rust (Melampsora larici-populina Kleb.) in poplar. Theoretical and Applied Genetics 88: 501-507.

Legionnet, A., H. Muranty and F. Lefevre (1999): Genetic variation of the riparian pioneer tree species Populus nigra. II. Variation in susceptibility to the foliar rust Melampsora larici-populina. Heredity 82: 318-327.

Newcombe, G. (1998): Association of Mmd1, a major gene for resistance to Melampsora medusae f. sp. deltoidae, with quantitative traits in poplar rust. Phytopathology 88: 114-121.

Newcombe, G., H. D. Bradshaw, Jr., G. A. Chastagner and R. F. STETTLER (1996): A major gene for resistance to Melampsora medusae, f. sp. deltoidae in a hybrid poplar pedigree. Phytopathology 86: 87-94.

Newcombe, G. and G. A. Chastagner (1993a): A leaf rust epidemic of hybrid poplar along the lower Columbia River caused by Melampsora medusae. Plant Disease 77: 528-531.

Newcombe, G. and G. A. Chastagner (1993b): First report of the Eurasian poplar leaf rust fungus, Melampsora laricipopulina, in North America. Plant Disease 77: 532-535. 
Newcombe, G., G. A. Chastagner, W. Schuette and B. J. STANTON (1994): Mortality among hybrid poplar clones in a stool bed following leaf rust caused by Melampsora medusae f. sp. deltoidae. Canadian Journal of Forest Research 24: 1984-1987.

Newcombe, G., B. Stirling and H. D. Bradshaw, JR. (2001): Abundant pathogenic variation in the new hybrid rust Melampsora $\times$ columbiana on hybrid poplar Phytopathology 91: 981-985.

Newcombe, G., B. Stirling, S. McDonald and H. D. BradSHAW JR. (2000): Melampsora $\times$ columbiana, a natural hybrid of $M$. medusae and $M$. occidentalis. Mycological Research 104: 261-274.

Pichot, C. and E. TeIssier DU CROs (1993a): Susceptibility of $P$. deltoides Bart. to Melampsora larici-populina and M. alli-populina I: Qualitative analysis of a $6 \times 6$ factorial mating design. Silvae Genetica 42: 179-188.

Pichot, C. and E. TEIssier DU Cros (1993b): Susceptibility of $P$. deltoides Bart. to Melampsora larici-populina and M. alli-populina II: Quantitative analysis of a $6 \times 6$ factorial mating design. Silvae Genetica 42: 188-199.

Prakash, C. S. and W. A. Heather (1986): Inheritance of resistance to races of Melampsora medusae in Populus deltoides. Silvae Genetica 35: 74-77.

RAJORA, O. P., L. Zsuffa and F. C. YEH (1994): Variation, inheritance and correlations of growth characters and Melampsora leaf rust resistance in full-sib families of Populus. Silvae Genetica 43: 219-226.

SCHREINER, E. J. (1959): Rating poplars for Melampsora leaf rust infection. U.S. Department of Agriculture Northeastern Forest Experiment Station Forest Research Notes 90: 3pp.

Stanton, B. J. (2005): The effect of reciprocal hybridization on reproduction of the intersectional cross, Populus $\times$ generosa. Forest Genetics 12: 131-140.
Stanton, B. J. and M. Villar (1996): Controlled reproduction of Populus, pp. 113-138. In: Biology of Populus and its implications for management and conservation, edited by R. F. Stettler, H. D. Bradshaw, JR., P. E. HeilMAN, and T. M. HiNCKLEY, NRC Research Press, National Research Council of Canada, Ottawa, ON, Canada.

Stettler, R. F., R. C. Fenn, P. E. Heilman and B. J. StanTON (1988): Populus trichocarpa $\times$ Populus deltoides hybrids for short rotation culture: variation patterns and 4-year field performance. Canadian Journal of Forest Research 18: 745-753.

Thielges, B. A. and J. C. AdAMs (1975): Genetic variation and heritability of Melampsora leaf rust resistance in eastern cottonwood. Forest Science 21: 278-282.

Thielges, B. A., A. Sabdono, R. J. Rousseau and C. S. PRAKASH (1989): Genetic variation and heritabilites of growth rate and Melampsora leaf rust resistance in a mid-south population of Populus deltoides Bartr., pp. 142-155. In: Recent developments in poplar selection and propagation techniques, Proc. IUFRO Working Party S2.02.10. Institute of Forest Tree Breeding of the Hessian Forest Research Station, Research Institute of Fast Growing Tree Species, Hann. Münden, Germany.

WANG, J. and B. J. VAN DER KAMP (1992): Resistance, tolerance, and yield of western black cottonwood infected by Melampsora rust. Canadian Journal of Forest Research 22: 183-192.

Woo, K.-S. and G. NEwCOMBE (2003): Absence of residual effects of a defeated resistance gene in poplar. Forest Pathology 33: 81-89.

YANG, R.-C., N. K. DHIR and F. C. YEH (1998): Intraclass correlation of polychotomous responses of lodgepole pine to infection of western gall rust: a simulation study. Silvae Genetica 47: 108-115.

\title{
Genetic variation between and within $e x$-situ native-provenance collections of Pinus radiata D. Don planted in Australia and New Zealand
}

\author{
By L. Bian ${ }^{1), 5)}$, W. J. GAPARE ${ }^{2,5), *)}$, M. Ivković ${ }^{2)}$, P. JefFerson ${ }^{3)}$ and H. X. Wu ${ }^{2,4)}$
}

(Received 11 ${ }^{\text {th }}$ June 2011)

\footnotetext{
1) The Key Laboratory of Forest Genetics \& Biotechnology, Nanjing Forestry University, Nanjing 210037, People's Republic of China.

2) CSIRO Plant Industry, GPO Box 1600, Canberra, ACT 2601, Australia.

3) Radiata Pine Breeding Company Ltd. PO Box 1127, Rotorua, New Zealand.

4) Umeå Plant Science Centre, Dept. Forest Genetics and Plant Physiology, Swedish University of Agricultural Sciences, SE-90183 Umeà, Sweden.

$\left.{ }^{5}\right)$ contributed equally.

*) Corresponding author: WAShington J. Gapare. Telephone: +6126246 4841, Fax: +6126246 4564. E-mail: Washington. Gapare@csiro.au
}

\begin{abstract}
A total of 1226 increment cores were sampled from two provenance trials of Pinus radiata D. Don planted in New Zealand (Kaingaroa) and Australia (Kangaroovale), to study variation and inheritance of wood density in selections from three mainland California natural populations: Año Nuevo, Monterey and Cambria. The study represents a back-to-back comparison of the same provenance and family material on contrasting sites between New Zealand and Australia. Monterey was significantly different to Año Nuevo and Cambria at Kaingaroa $(p<0.05)$, and had slightly higher density, whereas all provenances were almost identical and not significantly
\end{abstract}

